\title{
EURO DOMINANCE HYPOTHESIS \\ AND MONETARY POLICY \\ INDEPENDENCE - THE CZECH \\ PERSPECTIVE
}

\section{Łukasz Goczek, Dagmara Mycielska*}

\begin{abstract}
In this article, we investigate the actual level of monetary policy independence in the Czech Republic. We formulate the research agenda in terms of the Euro Dominance Hypothesis. The situation of the non-euro EU countries with derogation in terms of joining the EMU, like the Czech Republic, is similar to the pre-euro situation of the euro area countries, in which the problem of the stability of the European Mechanism System was predominant. We investigate the co-movement of interest rates between the Czech Republic and the Eurozone to assess the potential costs of monetary integration. Using cointegration and VECM methods we show that the ECB monetary policy influences monetary policy in the Czech Republic and the actual level of monetary independence in the Czech Republic is much lower than it is presumed. Therefore, we argue that for the Czech Republic the cost of the joining the EMU will be lower than expected.
\end{abstract}

Keywords: cointegration, VECM, monetary policy, interest rates, the Czech Republic JEL Classification: E43, E52, E58, F41, F42, C32

\section{Introduction}

The concept of German dominance in the European Monetary System (EMS) has gained popularity in the 1990s during a discussion on the stability of the EMS, in the theoretical framework of the "N-1" exchange rate paradigm. According to this theory, in an n-country currency union, there are n- 1 exchange rate parities and only one country can set monetary policy stance independently from the others. Moreover, that policy would become the monetary policy stance for all countries in the system of fixed exchange rates. The German Dominance Hypothesis (GDH) suggested that the Germany was an economically dominant country with all other countries of the European Exchange Rate Mechanism (ERM) being forced to follow monetary policy implemented by the Bundesbank. This problem became evident in the early 1990s at a time when various EU countries were forced to pursue different monetary strategies. This resulted in the ERM crisis.

This hypothesis was verified empirically and it was pointed out that the German monetary policy had the influence on the monetary policies of other European countries, but there was no evidence of its dominance (Karfakis, Moschos, 1990; Camarero, Ordóñez,

\footnotetext{
* $\quad$ Łukasz Goczek, Faculty of Economic Sciences, University of Warsaw, Warsaw, Poland (lgoczek@wne.uw.edu.pl);

Dagmara Mycielska, Faculty of Economic Sciences, University of Warsaw, Warsaw, Poland (dmycielska@wne.uw.edu.pl).

The article was prepared as a part of the Project "Measuring Monetary Independence in the Context of Joining Eurozone: Evidence from the Countries with Derogation" funded by the National Science Center granted by the Decision No. 2013/09/D/HS4/01051.
} 
2001). An introduction of euro finally closed the discussion on the GDH in the context of the first EMU members and the burden of interest moved to the non-euro EU countries and to the problem of domination of their monetary policies by the larger currency area, namely the Eurozone.

In this paper, we follow the idea of Euro Dominance Hypothesis (EDH) proposed by Kadow et al. (2013), who argue that the situation of non-euro EU countries with derogation in terms of euro is similar to the pre-euro situation of Eurozone countries and the European Mechanism System stability problem. In contrast to these authors, we investigate the problem of co-movement of interest rates in terms of costs of joining the EMU and the loss of the actual independence of domestic monetary policy in a small open economy.

The loss of domestic monetary policy independence is considered a fundamental cost of monetary integration. This argument lies at the centre of many studies on the costs and benefits and monetary integration in the countries of the EU with a derogation (Czech National Bank, 2007, p. 5; National Bank of Poland, 2009, p. 152; Zeman et al. 2006, p. 2). In contrast to these studies, it can be shown that monetary policy independence in terms of interest rates setting might be questionable in small open economies integrated financially with larger economic areas.

In the world of highly liberalized international capital flows an increase in domestic interest rates may result in adverse exchange rate movements that will then transfer both into inflation and into deterioration of the trade balance. This means that the domestic monetary policy cannot simultaneously aim at optimal levels of exchange and interest rates. It can therefore be postulated that the exchange rate stability will be fulfilled by domestic interest rates adjustment relative to the main trading partner's interest rates.

The observed co-movement of domestic and foreign interest rates might be a symptom of macroeconomic convergence and increasing synchronization of business cycles of Eurozone and other non-euro EU countries. In fact, in such case the central banks of both regions could react in the same way to disturbances that are global and exogenous to their decisions. The high degree of similarity in policies between the domestic and foreign central bank can therefore be a reflection of not so much a lack of an independence in an institutional sense, but rather of the symmetry of shocks affecting the domestic and foreign economies. Feridun (2006) suggested that linkages between interest rates of those countries might also be resulting from progressive harmonization of European banking and financial market regulations.

Another explanation of the observed co-movement of domestic and foreign interest rates could be the fear of floating phenomenon. In the presence of high level of capital mobility, the differences in interest rates might result in large capital flows and exchange rate volatility. If central bank, despite official declarations of a freely floating exchange rate, wants to limit the exchange rate volatility, changes of domestic interest rates in line with foreign interest rates might be in fact a form of a foreign exchange market intervention.

In this paper, we focus on the case of the Czech Republic. After the Cabinet changing at the beginning of 2014, the proposal of rapid euro adoption seems to be on the table again. Consequently, the problem of the actual costs and benefits of monetary integration needs to be discussed. The main hypothesis of the article is that the Czech interest rates are largely driven by the Eurozone rates and so even now, on the eve of accession to euro area, the Czech Republic cannot gain from a de facto independent monetary policy. This implies that the loss of independence of monetary policy cannot be treated as a cost of entering 
the common currency area since the Czech Republic has not enjoyed this independence in the first place.

We test for monetary independence using cointegration analysis of nominal interbank interest rates in the Czech Republic and the EMU. Based on the results of cointegration testing the Vector Error Correction Mechanism (VECM) model was constructed. We use the model to verify several hypotheses concerning the speed and asymmetry of adjustment between interest rates in the Czech Republic and the EMU that allow for determining the causality between monetary policies of both currency areas.

The paper is structured as follows. Section 2 briefly discusses the existing literature on the Euro Dominance Hypothesis and the problem of the actual level of monetary independence in the Czech Republic and other non-euro EU countries. In Section 3, we present the methodology and data. Section 4 presents the results of the empirical investigation, while Section 5 provides the discussion of the robustness of the results. Section 6 concludes with policy implications.

\section{Literature Review}

German and Eurozone monetary leadership hypothesis and the related suspected loss of monetary independence being the result of monetary unification have been widely discussed in literature. Using different econometric techniques and various data coverage, the authors of the empirical investigations surveyed below have reached inconclusive results.

The early 1990s analyses of the asymmetry of the EMS concentrated on the very first period of its operation. Among others, Fratianni and von Hagen (1990), von Hagen and Fratianni (1990) showed that there remained some space for independence in the system. Though Bundesbank set monetary policy independently in the long run, still there was no statistical evidence of a unidirectional causality. On the other hand, Karfakis and Moschos (1990) did not find evidence for rejecting the GDH using Granger causality technique.

Kirchgassner and Wolters (1993) argue that the analysis of the similarity between monetary policies should differentiate between the long and the short run. This problem was addressed in Camarerro and Ordonez (2001) who used cointegrated VAR and showed that the German dominance hypothesis should be rejected. Although Bundesbank's policy did influence the policies of the EMS member countries, its monetary policy was also dependent on others. The results suggested a long-run causality from the interest rates of the EMS countries to the German ones. On the other hand, Reade and Volz (2011) using cointegrated VAR method showed that the actual loss of monetary independence could refer exclusively to Germany. Other European countries that joined the euro area could not have lost what they did not have.

The surveyed authors directly referred to the symmetry and stability of the EMS and the Eurozone. However, the same problem can be analysed from the point of view of the cost of extending monetary integration to other countries. This is crucial especially for the non-euro EU members with derogation. The analyses of potential benefits and costs of monetary integration traditionally depict the loss of monetary independence as the major cost for integrating economy. This argument, however, is not supported in the data.

Gabrisch and Buscher (2011) confirmed the presence of a high level of correlation between short-term Euribor rates and short-term interbank interest rates in Denmark and Sweden. A similar thing was found for Sweden (Reade and Volz, 2010) and Poland (Goczek 
and Mycielska, 2014). The authors confirmed that the monetary policy independence could not be indicative of the benefits of staying outside the euro area. The same might apply for other CEE countries.

The Czech Republic's monetary policy independence was analysed in Cuaresma and Wójcik (2006). The authors investigate a DCC-MGARCH model of real interest rates in Germany and three Eastern European economies and conclude that these countries do not enjoy monetary policy independence. However, the analysis was carried out using data for years 1994-2002 and therefore included currency crisis in the Czech Republic, which could potentially render some of the conclusions less valid.

The same critique applies to Feridun (2006) who used the ECM methodology to test for the EDH in the Czech Republic and Slovakia. Results pointed to the existence of a longrun relationship between the Czech and German/Eurozone interest rates, though the EngleGranger two-step technique used in this research is dated, yet still correct. However, they used standard Granger causality test though it refers mainly to the short run relation. This problem is properly addressed in Kadow et al. (2013) as they test for weak exogeneity in global VAR setting for panel of all non-euro EU countries. They proved the EDH for those countries, except for the Hungary.

On the other hand, Windberger, Cuaresma, and Walde (2012) analyse several methods of estimation of the volatility interest rates and exchange rates to conclude that the Czech Republic has had a significant degree of monetary independence in the years 2002-2011. They also pointed out that incorporating structural breaks into the model might be crucial to obtain reliable estimates. However, they also do not discuss the diagnostic problems, which might be relevant for weekly frequency of interest rates.

\section{Methodology and Data}

The GDH/EDH can be formulated as a system of hypotheses introduced by von Hagen and Fratianni (1990) and consisting of the following elements: world insularity, independence from dominant country policy, dominant country policy independence. The cornerstone of our analysis is the second hypothesis: monetary policy of the Czech Republic significantly depends on the ECB policy. However, the Czech Republic's monetary independence hypothesis requires the third hypothesis to be positively verified that is the ECB does not take into account changes in the Czech monetary policy while setting its rates. To this end, we investigate the long-run relationship between Eurozone and Czech interest rates and analyse short run adjustment to this relation. We follow Camarerro and Ordonez (2001) and Kadow et al. (2013) and use cointegrated VAR framework that allows for distinction between the long and the short run.

Let us define $r_{1}$ as a domestic interest rate and $r_{2}$ as an international interest rate. The bivariate cointegrated VAR of order $K$ can be formulated as follows:

$$
\Delta r_{t}=\sum_{i=1}^{K-1} \Pi_{i} \Delta r_{t-i}+\alpha \beta^{\prime} r_{t-1}+\Phi d_{t}+\varepsilon_{t}
$$

where $r_{t}$ is the vector of interest rates and random term $\varepsilon_{t} \sim N\left(0, \sigma^{2}\right)$ and is uncorrelated over $t$. $d_{t}$ is the vector of deterministic elements. The short run dynamics are described by $\Pi$, the adjustment to the long-run equilibrium is denoted by $\alpha \beta^{\prime}$, where $\alpha$ is the vector of loading coefficients and $\beta$ quantifies long-run equilibrium relations. 
Traditionally, the GDH had been tested within the Granger causality framework. As it was mentioned, standard Granger causality test does not differentiate between the long and the short run. Thus, it might be used to analyse the short-run relation between interest rates only. Therefore, the more appropriate technique would be to test for the weak exogeneity of Eurozone in the Czech interest rates setting. Kadow et al. (2013) are using this method when constructing their model of Eurozone and CEE countries' interest rates and then testing validity of this assumption. In our research, we do not impose this assumption on our model prior to estimation.

In terms of Equation $1 r_{2, t}$ is weakly exogenous if $\beta^{\prime} r_{1, t-1}$ do not enter the equation for $\Delta r_{2, t}$. Therefore testing for the dominant role of the ECB in the CEEC interest rates setting process would be testing for weak exogeneity of euro rates $\left(r_{2, t}\right)$. In other words, we test for $\alpha_{2}=0$. Significance and signs of the $\alpha$ coefficients indicate how interest rate reacts to deviations from the cointegrating relation. The knowledge of $\beta$ coefficients allows for the analysis of the properties of the long-run equilibrium. The cointegrating vector $\beta^{\prime} r_{t-1}$ can then be rewritten as follows:

$$
\beta^{\prime} r_{t-1}=\left(\beta_{0}, \beta_{1}, \beta_{2}, \beta_{3}\right)\left(\begin{array}{c}
1 \\
t \\
r_{1, t} \\
r_{2, t}
\end{array}\right)=\beta_{0}+\beta_{1} t+\beta_{2} r_{1, t}+\beta_{3} r_{2, t}
$$

Short-term money market interest rates are commonly used as a proxy for monetary policy realization (Bernanke and Blinder, 1992). Moreover, Coricelli et al. (2006) empirically proved the full transmission of monetary policy rates on short-term money market rates in CEE countries. Therefore, we are using 3-month interbank interest rates with daily, weekly, and monthly frequency: Pribor interest rate for Czech and Euribor interest rate for EMU. We analyse the scope of monetary independence in floating exchange rate regime framework. The Czech Republic officially introduced floating exchange rate in 1997, but we excluded the 1998-2000 disinflation episode. Therefore, the dataset ranges from January 2001 to September 2012, when the two-week repo rate was set on the technical zero and the CNB (Czech National Bank) began using the exchange rate as an additional instrument of monetary policy. The time span should be sufficient to detect cointegration and it is similar to the other research on the GDH/EDH.

\section{Empirical Model Results}

We examined the date for presence of a unit root by means of the ADF test and the DF-GLS test (Dolado et al., 1990; Elliott et al., 1996), allowing for an intercept as the deterministic component. The unit root null hypothesis cannot be rejected at the $5 \%$ level in all cases. KPSS stationarity tests (Kwiatkowski et al., 1992) confirm this result. The same procedure was applied to the series in first differences obtaining the opposite results. According to the results presented in Table A1 in the Appendix all the examined time series are I(1).

Next, the vector autoregressive model on levels was build. Analysis of Schwarz Information Criteria indicated that the number of lags should be 5, 2 or 4 for daily, weekly, and monthly data frequency, respectively (these results can be found in Table A2) Then the Johansen's $(1988,1991)$ approach was used in order to determine the rank of matrix $\Pi$ in Equation 1. The summary of results of both Trace and Maximum Eigenvalue tests for various trend specifications are reported in Table 1. 


\begin{tabular}{|l|l|l|l|c|c|}
\hline \multicolumn{5}{|c}{ Number of Cointegrating Relations by Model } \\
\hline \multirow{5}{*}{ Data Frequency } & \multicolumn{1}{|c|}{ VAR Type } & \multicolumn{2}{c|}{ Test Type } & Trace & Max-Eig \\
\hline \multirow{5}{*}{ Monthly } & None & No Intercept & No Trend & 1 & 1 \\
\cline { 2 - 6 } & None & Intercept & No Trend & 1 & 1 \\
\cline { 2 - 6 } & Linear & Intercept & No Trend & 1 & 1 \\
\cline { 2 - 6 } & Linear & Intercept & Trend & 0 & 1 \\
\cline { 2 - 6 } & Quadratic & Intercept & Trend & 0 & 2 \\
\hline \multirow{5}{*}{ Weekly } & None & No Intercept & No Trend & 1 & 1 \\
\cline { 2 - 6 } & None & Intercept & No Trend & 1 & 1 \\
\cline { 2 - 6 } & Linear & Intercept & No Trend & 1 & 1 \\
\cline { 2 - 6 } & Linear & Intercept & Trend & 1 & 1 \\
\cline { 2 - 6 } & Quadratic & Intercept & Trend & 2 & 2 \\
\hline & None & No Intercept & No Trend & 1 & 1 \\
\cline { 2 - 6 } & None & Intercept & No Trend & 1 & 1 \\
\cline { 2 - 6 } & Linear & Intercept & No Trend & 1 & 1 \\
\cline { 2 - 6 } & Linear & Intercept & Trend & 1 & 0 \\
\cline { 2 - 6 } & Quadratic & Intercept & Trend & 1 & 1 \\
\hline
\end{tabular}

Source: authors

The majority of test results suggest that the number of cointegrating relations is equal to one, but not in all specifications. Therefore, we need to discriminate between various specifications with different deterministic components. Lütkepohl (2005) suggested using minimization of informational criteria to solve the deterministic components selection problem as the models are nested. AIC information criteria gives better results in terms of mean square error for low order VAR (Lütkepohl, 2005). Table 2 presents the results of these estimations. The results suggest that regardless of data frequency the most preferred model is the model with one equation with no intercept and no trend. Johansen's test results presented in Table A3 confirms that the chosen model specification with no intercept and no trend is statistically significant and robust to the frequency of the data. The existence of a single cointegrating relationship confirms that monetary policy in both areas displays co-movement. That result confirms the main hypothesis of the article.

Cointegrated VAR estimation results are shown in Table 3. According to the results, the euro interest rate transmission is close to full transmission (a positive innovation in the EURIBOR by 100 basis points relates to $87-93$ basis points hike in PRIBOR). In other words, the results confirm the euro dominance hypothesis as the Euribor is very significant for the determination of Pribor in the long run. This result is in line with analyses done with different method (Kadow et al., 2013). 


\begin{tabular}{|c|c|c|c|c|c|c|}
\hline \multicolumn{4}{|c|}{ Information Criteria by Rank and Model } & \multirow{2}{*}{\multicolumn{3}{|c|}{$\begin{array}{c}\text { AIC by Rank (columns) } \\
\text { and Model (rows) }\end{array}$}} \\
\hline \multirow[t]{2}{*}{ Data Frequency } & \multirow{2}{*}{ VAR Type } & \multicolumn{2}{|c|}{ Test Type } & & & \\
\hline & & & & 0 & 1 & 2 \\
\hline \multirow{5}{*}{ Monthly } & None & No Intercept & No Trend & -2.738 & $-2.803^{*}$ & -2.763 \\
\hline & None & Intercept & No Trend & -2.738 & -2.789 & -2.747 \\
\hline & Linear & Intercept & No Trend & -2.718 & -2.780 & -2.747 \\
\hline & Linear & Intercept & Trend & -2.718 & -2.766 & -2.742 \\
\hline & Quadratic & Intercept & Trend & -2.691 & -2.752 & -2.742 \\
\hline \multirow{5}{*}{ Weekly } & None & No Intercept & No Trend & -7.299 & $-7.326^{*}$ & -7.316 \\
\hline & None & Intercept & No Trend & -7.299 & -7.324 & -7.312 \\
\hline & Linear & Intercept & No Trend & -7.299 & -7.321 & -7.312 \\
\hline & Linear & Intercept & Trend & -7.299 & -7.319 & -7.313 \\
\hline & Quadratic & Intercept & Trend & -7.294 & -7.316 & -7.313 \\
\hline \multirow{5}{*}{ Daily } & None & No Intercept & No Trend & -7.299 & $-7.326^{*}$ & -7.316 \\
\hline & None & Intercept & No Trend & -7.299 & -7.324 & -7.312 \\
\hline & Linear & Intercept & No Trend & -7.299 & -7.321 & -7.312 \\
\hline & Linear & Intercept & Trend & -7.299 & -7.319 & -7.313 \\
\hline & Quadratic & Intercept & Trend & -7.294 & -7.316 & -7.313 \\
\hline
\end{tabular}

Note: ${ }^{*}$ depicts the minimum value

Source: authors

Once the cointegrating vector was identified, the second part of monetary policy independence hypothesis consists of testing the weak exogeneity of Euribor in the VECM model. In terms of Johansen's method, this means that the Czech interest rates do not enter the Euribor equation through the error correction. The estimated short run coefficient of Euribor $\left(\alpha_{2}\right)$ for daily data is negative and significant. This suggests that for daily data the weakly exogeneity of Euribor cannot be rejected i.e. - that changes in Pribor determine Euribor. In this analysis, we do not control for any other common factor that might have influence on interest rates in both currency areas. This may explain the spurious result suggesting that Euribor is dependent from the Czech interest rates. Other explanation of this counter intuitive result relates to the data frequency. Usually the monthly data are used in analyses of longrun monetary convergence (Kadow et al., 2013). The monthly data for interest rates should portray the long-run relationships to a much greater extent (Hakkio, Rush, 1991) given the noise and jumps in daily interest rates volatility, and we conclude, that this is in fact the case. 


\begin{tabular}{|c|c|c|c|c|c|c|}
\hline Data frequency & \multicolumn{2}{|c|}{ Monthly } & \multicolumn{2}{c|}{ Weekly } & \multicolumn{2}{c|}{ Daily } \\
\hline \multirow{4}{*}{$\beta_{3}$} & \multicolumn{2}{|c|}{-0.919296} & \multicolumn{2}{c|}{-0.877085} & \multicolumn{2}{c|}{-0.934587} \\
\cline { 2 - 7 } & \multicolumn{2}{|c|}{$(0.04723)$} & \multicolumn{2}{|c|}{$(0.04312)$} & \multicolumn{2}{c|}{$(0.04236)$} \\
\cline { 2 - 7 } & \multicolumn{2}{|c|}{$[0.0000]$} & \multicolumn{2}{c|}{$[0.0000]$} & \multicolumn{2}{c|}{$[0.0000]$} \\
\hline \multirow{2}{*}{$\begin{array}{c}\text { Error } \\
\text { Correction }\end{array}$} & $\begin{array}{c}\boldsymbol{a}_{1} \\
\text { (PRIBOR) }\end{array}$ & $\begin{array}{c}\boldsymbol{a}_{\mathbf{2}} \\
\text { (EURIBOR) }\end{array}$ & $\begin{array}{c}\boldsymbol{a}_{\mathbf{1}} \\
\text { (PRIBOR) }\end{array}$ & $\begin{array}{c}\boldsymbol{a}_{2} \\
\text { (EURIBOR) }\end{array}$ & (PRIBOR) & (EURIBOR) \\
\hline \multirow{4}{*}{} & -0.075522 & -0.010381 & -0.009163 & -0.003699 & -0.003229 & -0.001746 \\
\cline { 2 - 7 } & $(0.01868)$ & $(0.01875)$ & $(0.00249)$ & $(0.00240)$ & $(0.00086)$ & $(0.00052)$ \\
\cline { 2 - 7 } & {$[0.0000]$} & {$[0.5807]$} & {$[0.0000]$} & {$[0.1243]$} & {$[0.0000]$} & {$[0.0000]$} \\
\hline
\end{tabular}

Note: () standard errors, [] p-values

Source: authors

That being said we show that the short-run coefficient of Pribor $\left(\alpha_{1}\right)$ is negative and significant statistically. That means that the behaviour of this rate displays reversion to the estimated long-run cointegration equation and the half of the adjustment takes about nine months. Thus, it can be argued that the relationship between interest rates in the two areas is asymmetric in the way that Pribor is adjusting to changes in Euribor, but no other way around.

Overall, the main results point to the existence of Czech Republic's monetary policy dependence on ECB monetary policy and to the ECB policy independence from Czech monetary policy. Thus we may conclude that there is an asymmetry in monetary policies so the EDH in relation to the Czech Republic was confirmed true. In other words, there is a long-run steady-state relationship between the interest rates in Czech Republic and the Eurozone. In addition, the Czech interest rates adjust to the changes in ECB interest rates for a given disequilibrium to the steady state. As there is no constant in the cointegrating vector, that might be seen as the lack of risk premium for investing in the Czech Republic over Eurozone in the long run. The overall results allow for arguing that the degree of monetary independence in the Czech Republic is low - despite the monetary authority claims of targeting inflation, this monetary regime does not insulate this small open economy from the changes in monetary policy performed by the ECB.

\section{Robustness Test - Incorporating the Exchange Rate into the Model}

The traditional GDH testing related to the asymmetry of fixed exchange rates system justifies excluding the exchange rate flexibility from the model. In terms of EDH the potential criticism concerns the possibility of testing a model with incomplete specification. Indeed, according to the theory of uncovered interest rate parity, analysis of the relationship between interest rates of the two countries should take into account changes in the nominal exchange rate. However, as Juselius (2007) explains, each existing cointegration vector relates to a long-term relationship that will be preserved in all of the more general specifications of the model. Therefore, as explained in Reade and Volz (2010) making 
of an econometric model based on an established cointegrating relationship solely for the interest rates should transfer to more complex models involving these rates, e.g. models relating to interest rate parities take into account the exchange rate, the output gap, inflation and other factors affecting the external balance of the country.

Even though any omission of a variable should not significantly affect the obtained results, we tested the robustness of our results by incorporating the exchange rates into the model. Let us consider three time series for domestic $\left(r_{1}\right)$ and international interest rates $\left(r_{2}\right)$ and the exchange rate depreciation $(e)$ that form a trivariate data vector. The three variables are used to form a VAR model described by Equation 1, where $r_{t}$ is now the vector of interest rates and exchange rate depreciation. The cointegrating vector $\beta^{\prime} r_{t-1}$ can now be rewritten as follows:

$$
\beta^{\prime} r_{t-1}=\left(\beta_{0}, \beta_{1}, \beta_{2}, \beta_{3}, \beta_{4}\right)\left(\begin{array}{c}
1 \\
t \\
r_{1, t} \\
r_{2, t} \\
e_{t}
\end{array}\right)=\beta_{0}+\beta_{1} t+\beta_{2} r_{1, t}+\beta_{3} r_{2, t}+\beta_{4} e_{t} \text {. }
$$

The econometric procedure was the same as for the base model, but performed only in the monthly data. The monthly average of the Czech and Eurozone interbank interest rates (Pribor and Euribor) was used as a proxy for the realization of monetary policies. The changes of euro exchange rates were calculated in terms of monthly averages. First, the results of KPSS stationarity tests confirm that all variables are I(1). Next, the Johansen's test result given the lags obtained by the Schwarz information criteria suggests the existence of one cointegrating vector, though not in all specifications (Table A4). According to AIC information criteria, the most preferred model is the model with two cointegrating vectors with intercept and trend (Table A5). The summarized cointegrated VAR estimation results are presented in Table 4.

Table 4 | Cointegrated VAR Estimation Results

\begin{tabular}{|c|c|c|c|c|c|c|}
\hline $\begin{array}{c}\text { Cointegrating } \\
\text { Equation }\end{array}$ & \multicolumn{3}{|c|}{ Pribor } & \multicolumn{3}{|c|}{ CZK/EUR } \\
\hline \multirow{3}{*}{$\beta_{3}$} & \multicolumn{3}{|c|}{-0.632715} & \multicolumn{3}{|c|}{-0.085045} \\
\hline & \multicolumn{3}{|c|}{$(0.06901)$} & \multicolumn{3}{|c|}{$(0.01492)$} \\
\hline & \multicolumn{3}{|c|}{$[0.0000]$} & \multicolumn{3}{|c|}{$[0.0000]$} \\
\hline \multirow[t]{4}{*}{$\begin{array}{c}\text { Error } \\
\text { Correction }\end{array}$} & $\begin{array}{c}a_{1,1} \\
\text { (PRIBOR) }\end{array}$ & $\begin{array}{c}a_{2,1} \\
\text { (CZK/EUR) }\end{array}$ & $\begin{array}{c}a_{3,1} \\
\text { (EURIBOR) }\end{array}$ & $\begin{array}{c}a_{1,2} \\
\text { (PRIBOR) }\end{array}$ & $\begin{array}{c}a_{2,2} \\
\text { (CZK/EUR) }\end{array}$ & $\begin{array}{c}a_{3,2} \\
\text { (EURIBOR) }\end{array}$ \\
\hline & -0.078902 & 0.036486 & -0.035391 & -0.570089 & -0.153862 & 0.080116 \\
\hline & $(0.03043)$ & $(0.01019)$ & $(0.02644)$ & $(0.13123)$ & $(0.04392)$ & $(0.11402)$ \\
\hline & [0.0117] & {$[0.0000]$} & [0.1830] & {$[0.0000]$} & {$[0.0000]$} & [0.4835] \\
\hline
\end{tabular}

Note: () standard errors, [] p-values

Source: authors 
In terms of our main hypothesis the difference between the results for this analysis and the baseline one is quantitative rather than qualitative. Incorporating exchange rate into the model weakens the base conclusions: according to the results, the influence of euro interest rates on Pribor is lower than in the base model though still significant. However, part of the variation has been taken up by the trend term. In sum, the existence of the cointegrating vector still indicates the co-movement of the Czech and ECB interest rates. Therefore, this evidence is in favour of the Euro dominance hypothesis that has proved itself to be robust.

The results point to the existence of a second cointegrating equation determining the exchange rate. In this equation, Euribor has a positive and significant impact on the exchange rate and this is consistent with the theory. As seen by the significant and negative coefficient $\alpha_{2}$, the residuals from this equation, which can be understood as deviations in Czech koruna depreciation from this relationship, force the CNB to intervene with a change in the domestic interest rate. This fear of floating behaviour relates to an increase in Pribor rates if the koruna depreciates more than 80 basis points in reaction to a 100 basis points increase in Euribor.

The weak exogeneity of Euribor was confirmed for both Pribor and the exchange rate. The short-run coefficient of Pribor in Pribor equation is again significant statistically and negative which means that the behaviour of this rate displays reversion to the estimated long-run cointegration equation. Overall conclusion is that the Czech monetary policy is dependent on the ECB policy stance.

\section{Conclusion}

The loss of independence of domestic monetary policy is regarded as the one of the most important costs of monetary integration. However, the insights from theoretical considerations suggest that the actual level of monetary policy independence in a small open economy is significantly limited, even in the case of a floating exchange rate (Edwards, 2015). Therefore a small open economy, such as the Czech Republic, with highly integrated financial and banking markets, does not lose monetary independence by joining euro currency area simply because this is independence is limited even now.

In this paper we test for the relevance of this statement in terms of the euro dominance hypothesis. The results support the view of an asymmetric relation between ECB and CNB policy stance. The euro interest rates are weakly exogenous, which means that the Czech monetary policy does not influence the ECB strategy. However, changes in euro interest rates affect the Czech interest rates. Thus the independence from dominant country policy hypothesis was rejected and the results did not allow for rejecting the dominant country policy independence. This is the cornerstone of our analysis: monetary policy of the Czech Republic significantly depends on the ECB policy, but the ECB does not take into account changes in the Czech monetary policy while setting its rates.

The proposed model does not allow us to provide an exact explanation of these empirical results for the observed phenomenon. However, a few explanations can be suggested. The first reason for the co-movements of interest rates might be due to an increasing correlation between business cycles in the Czech and EU economies. The transmission of euro interest rates can be then a result of the continuing process of integration supported by increasing trade and financial flows increasing the stakes of divergence from the dominant economy interest rates. The second explanation for the observed high level of correlation 
of monetary policy in the two areas is a simultaneous reaction of both the ECB and the CNB to a common or global component of inflation: central banks of both areas simply react to common international shocks.

The results of our analysis can be also discussed in relation to the process of financial integration within the European Union. The co-movement of interest rates is not only the result of a continuing real convergence of the EU economies but predominantly reflects the harmonization of financial and banking market regulations. This is evident since recent divergence of growth rates being the result of debt crisis in some Eurozone crisis did not constrict the cointegrating relationship between Czech and ECB interest rates.

Whatever the explanation, monetary policy in the Czech Republic seems to be highly dependent on ECB policy. The Czech interest rates are largely driven by the Eurozone rates and so even now, on the eve of accession to euro area, the actual scope of monetary policy independence in the Czech Republic is limited. The loss of independence of monetary policy cannot be treated as a major cost of entering the common currency area since the Czech Republic has not enjoyed this even now. Therefore, the costs of joining the EMU by the Czech Republic could be potentially smaller than it is commonly seen. The CNB seems to have understood limitations to its monetary policy independence in a rational (in view of our results) pronouncement to move to a more exchange rate driven mechanism in decision on monetary policy stance in the Czech Republic. 


\section{Appendix}

Table A1 | Summary of Unit Root Tests

\begin{tabular}{|c|c|c|c|c|}
\hline & $\begin{array}{l}\text { Pribor } \\
\text { in levels }\end{array}$ & $\begin{array}{c}\text { First } \\
\text { differences } \\
\text { of Pribor }\end{array}$ & $\begin{array}{l}\text { Euribor } \\
\text { in levels }\end{array}$ & $\begin{array}{c}\text { First } \\
\text { differences } \\
\text { of Euribor }\end{array}$ \\
\hline \multicolumn{5}{|c|}{ Augmented Dickey-Fuller test } \\
\hline $\begin{array}{l}\text { Augmented Dickey-Fuller } \\
\text { test statistic }\end{array}$ & -1.881784 & -8.897111 & -1.055212 & -10.59776 \\
\hline $1 \%$ Critical & -3.440929 & -3.440929 & -3.440841 & -3.440841 \\
\hline $5 \%$ Critical & -2.866099 & -2.866099 & -2.866060 & -2.866060 \\
\hline $10 \%$ Critical & -2.569257 & -2.569257 & -2.569236 & -2.569236 \\
\hline \multicolumn{5}{|c|}{ Dickey-Fuller-GLS test } \\
\hline DF-GLS tau statistic & 0.612101 & -7.969356 & 0.674482 & -6.785498 \\
\hline $1 \%$ Critical & -2.568790 & -2.568790 & -2.568758 & -2.568758 \\
\hline 5\% Critical & -1.941347 & -1.941347 & -1.941343 & -1.941343 \\
\hline $10 \%$ Critical & -1.616347 & -1.616347 & -1.616350 & -1.616350 \\
\hline \multicolumn{5}{|c|}{ Kwiatkowski-Phillips-Schmidt-Shin test } \\
\hline KPSS statistic & 1.336057 & 0.217988 & 1.024880 & 0.145072 \\
\hline $1 \%$ Critical & 0.739 & 0.739 & 0.739 & 0.739 \\
\hline $5 \%$ Critical & 0.463 & 0.463 & 0.463 & 0.463 \\
\hline $10 \%$ Critical & 0.347 & 0.347 & 0.347 & 0.347 \\
\hline \multicolumn{5}{|c|}{ Zivot-Andrews unit root test with a break in intercept } \\
\hline Minimum t-statistic & -3.219 & -11.131 & -5.43 & -10.539 \\
\hline $1 \%$ Critical & -5.43 & -5.43 & -5.43 & -5.43 \\
\hline 5\% Critical & -4.80 & -4.80 & -4.80 & -4.80 \\
\hline \multicolumn{5}{|c|}{ Zivot-Andrews unit root test with a break both in intercept and trend } \\
\hline Minimum t-statistic & -2.852 & -11.123 & -3.440 & -10.832 \\
\hline $1 \%$ Critical & -5.57 & -5.57 & -5.57 & -5.57 \\
\hline 5\% Critical & -5.08 & -5.08 & -5.08 & -5.08 \\
\hline
\end{tabular}

Source: authors 
Table A2 | Schwarz Information Criteria for Unrestricted VAR

\begin{tabular}{|c|c|c|c|}
\hline Lags & Daily & Weekly & Monthly \\
\hline 1 & -10.94 & -6.62 & -2.06 \\
\hline 2 & -11.78 & $-7.80^{*}$ & -2.79 \\
\hline 3 & -11.77 & -7.75 & -2.80 \\
\hline 4 & -11.73 & -7.76 & $-2.80 *$ \\
\hline 5 & $-11.79 *$ & -7.76 & -2.55 \\
\hline 6 & -11.60 & -7.72 & -2.44 \\
\hline 7 & -11.57 & -7.69 & -2.32 \\
\hline 8 & -11.51 & -7.65 & -2.18 \\
\hline 9 & -11.46 & -7.62 & -2.09 \\
\hline 10 & -11.40 & -7.57 & -1.96 \\
\hline 11 & -11.40 & -7.54 & -1.85 \\
\hline 12 & -11.43 & -7.50 & -1.70 \\
\hline 13 & -11.37 & -7.47 & -1.57 \\
\hline 14 & -11.28 & -7.45 & -1.43 \\
\hline 15 & -11.19 & -7.43 & -1.30 \\
\hline 16 & -11.12 & -7.40 & -1.22 \\
\hline 17 & -11.09 & -7.37 & -1.07 \\
\hline 18 & -11.01 & -7.35 & -0.97 \\
\hline 19 & -10.94 & -7.32 & -0.84 \\
\hline 20 & -10.86 & -7.29 & -0.72 \\
\hline 21 & -10.78 & -7.25 & -0.59 \\
\hline 22 & -10.76 & -7.22 & -0.48 \\
\hline 23 & -10.68 & -7.18 & -0.40 \\
\hline 24 & -10.62 & -7.16 & -0.27 \\
\hline 25 & -10.55 & -7.12 & -0.12 \\
\hline 26 & -10.48 & -7.08 & 0.03 \\
\hline 27 & -10.39 & -7.04 & 0.09 \\
\hline 28 & -10.32 & -7.00 & 0.24 \\
\hline 29 & -10.23 & -6.97 & 0.37 \\
\hline 30 & -10.15 & -6.93 & 0.53 \\
\hline
\end{tabular}

Source: authors 
Table A3 | Johansen Test Results for the No Intercepts, No Trend Specification of Model

\begin{tabular}{|l|l|r|r|}
\hline Data frequency & Hypothesised Number of CE(s) & None & At most 1 \\
\hline \multirow{4}{*}{ Monthly } & Trace Statistic & 19.36606 & 2.474601 \\
\cline { 2 - 4 } & 0.05 Critical Value & 12.32090 & 4.129906 \\
\cline { 2 - 4 } & Prob. & $0.0028^{*}$ & 0.1367 \\
\hline \multirow{4}{*}{ Weekly } & Trace Statistic & 16.38931 & 1.906355 \\
\cline { 2 - 4 } & 0.05 Critical Value & 12.3209 & 4.129906 \\
\cline { 2 - 4 } & Prob. & $0.0099^{*}$ & 0.1970 \\
\hline \multirow{3}{*}{ Daily } & Trace Statistic & 25.54454 & 1.430815 \\
\cline { 2 - 4 } & 0.05 Critical Value & 12.3209 & 4.129906 \\
\cline { 2 - 4 } & Prob. & $0.0002^{*}$ & 0.2713 \\
\hline
\end{tabular}

Source: authors

Table A4 | Summary of Cointegration Test Results

\begin{tabular}{|l|c|c|c|c|c|}
\hline \multicolumn{7}{|c|}{ Number of Cointegrating Relations by Model } \\
\hline VAR Type & None & None & Linear & Linear & Quadratic \\
\hline \multirow{3}{*}{ Test Type } & No Intercept & Intercept & Intercept & Intercept & Intercept \\
\cline { 2 - 6 } & No Trend & No Trend & No Trend & Trend & Trend \\
\hline Trace & 1 & 1 & 1 & 2 & 3 \\
\hline Max-Eigenvalue & 1 & 1 & 1 & 2 & 3 \\
\hline
\end{tabular}

Source: authors

Table A5 | Information Criteria Minimization Problem

\begin{tabular}{|l|c|c|c|c|c|}
\hline \multicolumn{7}{|c|}{ Akaike Information Criteria by Rank (rows) and Model (columns) } \\
\hline Data Trend & None & None & Linear & Linear & Quadratic \\
\hline \multirow{2}{*}{$\begin{array}{l}\text { Rank or } \\
\text { Number of CEs }\end{array}$} & No Intercept & Intercept & Intercept & Intercept & Intercept \\
\cline { 2 - 6 } & No Trend & No Trend & No Trend & Trend & Trend \\
\hline $\mathbf{0}$ & -5.302623 & -5.302623 & -5.329897 & -5.329897 & -5.299921 \\
\hline $\mathbf{1}$ & -5.435943 & -5.468999 & -5.453228 & -5.464896 & -5.443033 \\
\hline $\mathbf{2}$ & -5.382003 & -5.410079 & -5.408346 & $-5.543875^{*}$ & -5.530612 \\
\hline $\mathbf{3}$ & -5.295816 & -5.330004 & -5.330004 & -5.484490 & -5.484490 \\
\hline
\end{tabular}

Note: * depicts the minimum value

Source: authors 


\section{References}

Baranowski, P. (2014). Reguły polityki pieniężnej w Polsce. Podejście ilościowe (Monetary Policy Rules in Poland - Quantitative Approach). Poland: University of Lodz.

Bernanke, B., Blinder, A. (1992). The Federal Funds Rate and the Channels of Monetary Transmission. The American Economic Review, 82(4), 901-921.

Camarero, M., Ordóñez J. (2001). Who Is Ruling Europe? Empirical Evidence on the German Dominance Hypothesis. Empirical Economics, 26, 623-650. DOI: 10.1007/s001810100075.

Coricelli, F., Égert, B., MacDonald, R. (2006). Monetary Transmission in Central and Eastern Europe: Gliding on a Wind of Change. Focus on European Economic Integration, Oesterreichische Nationalbank, 1, pp. 44-87. DOI: 10.2139/ssrn.949468.

Cuaresma, J. C., Wojcik, C. (2006). Measuring Monetary Independence: Evidence from a Group of New EU Member Countries. Journal of Comparative Economics, 34(1), 24-43. DOI: $10.1016 /$ j.jce.2005.12.003.

Czech National Bank (2007). The Czech Republic's Updated Euro-area Accession Strategy. Joint Document of the Czech Government and the Czech National Bank.

Dolado, J. J., Jenkinson, T., Sosvilla-Rivero, S. (1990). Cointegration and Unit Roots. Journal of Economic Surveys, 4(3), 249-273. DOI: 10.1111/j.1467-6419.1990.tb00088.x.

Edwards, S. (2015). Monetary Policy Independence under Flexible Exchange Rates: An Illusion? NBER Working Paper No. 20893. DOI: 10.3386/w20893.

Elliott, G., Rothenberg, T., Stock J. (1996). Efficient Tests for an Autoregressive Unit Root. Econometrica, 64(4), 813-836. DOI: 10.2307/2171846.

Feridun, M. (2006). An Investigation of the German Dominance Hypothesis in the Context of Eastern Enlargement of the EU. Prague Economic Papers, 15(2), 172-182.

DOI: 10.18267/j.pep.283.

Fratianni, M., von Hagen, J. (1990). German Dominance in the EMS: The Empirical Evidence. Open Economics Review, 1(1), 67-87. DOI: 10.1007/bf01886176.

Gabrisch, H., Buscher, H. S. (2011). What Might Central Banks Lose or Gain in Case of Euro Adoption - A GARCH-Analysis of Money Market Rates for Sweden, Denmark and the UK. IWH Discussion Papers No. 9.

Goczek, L., Mycielska, D. (2014). Gotowi na euro? Badanie empiryczne faktycznej swobody polskiej polityki pieniężnej. Bank and Credit, 45(3), 267-290.

Hagen, J. von, Fratianni, M. (1990). German Dominance in the EMS: Evidence from Interest Rates. Journal of International Money and Finance, 9(4), 358-375.

DOI: 10.1016/0261-5606(90)90016-s.

Hakkio, C. S., Rush, M. (1991). Cointegration: How Short Is the Long Run? Journal of International Money and Finance, 10(4), 571-581. DOI: 10.1016/0261-5606(91)90008-8.

Johansen, S. (1988). Statistical Analysis of Cointegrated Vectors. Journal of Economic Dynamics and Control, 12, 231-254.

Johansen, S. (1991). Estimation and Hypothesis of Cointegration Vectors in Gaussian Vector Autoregressive Models. Econometrica, 59(6), 1551-1580. DOI: 10.2307/2938278.

Juselius, K. (2007). The Cointegrated VAR Model: Methodology and Applications. Advanced Texts in Econometrics, Oxford University Press, Oxford.

Kadow, A., Cerrato, M., MacDonald R., Straetmans S. (2013). Does the Euro Dominate Central and Eastern European Money Markets? Journal of International Money and Finance, 32, pp. 700-718. DOI: 10.1016/j.jimonfin.2012.06.004. 
Karfakis, C. J., Moschos, D. M. (1990). Interest Rate Linkages within the European Monetary System: A Time Series Analysis: Note. Journal of Money, Credit and Banking, 22(3), 388-394. DOI: $10.2307 / 1992567$.

Kirchgassner, G., Wolters, J. (1993). Does the DM Dominate the Euro Market? An Empirical Investigation. The Review of Economics and Statistics, 75(4), 773-778. DOI: $10.2307 / 2110039$.

Kwiatkowski, D., Phillips, P. C. B., Schmidt, P., Shin, Y. (1992). Testing the Null Hypothesis of Stationarity against the Alternative of a Unit Root. Journal of Econometrics, 54(1-3), 159-170. DOI: 10.1016/0304-4076(92)90104-y.

Lütkepohl, H. (2005). New Introduction to Multiple Time Series Analysis. Berlin: Springer.

National Bank of Poland (2009). Report on Full Membership of the Republic of Poland in the Third Stage of the Economic and Monetary Union. Warszawa: National Bank of Poland.

Reade, J., Volz, U. (2010). Too Much To Lose, Or More To Gain? Should Sweden Join the Euro? University of Birmingham Discussion Paper No. 10-13.

Reade, J., Volz, U. (2011). Leader of the Pack? German Monetary Dominance in Europe Prior to EMU. Economic Modelling, 28(1-2), 239-250. DOI: 10.1016/j.econmod.2010.09.006.

Windberger, T., Crespo Cuaresma, J., Walde, J. (2012). Dirty Floating and Monetary Independence in Central and Eastern Europe - The Role of Structural Breaks. Faculty of Economics and Statistics, University of Innsbruck Working Papers 2012-21.

Zeman, J., Šuster, M., Benčík, M., Nemec, M. (2006). Loss of Independent Monetary Policy after Euro Adoption. BIATEC, 14(8), 2-7. 